\title{
PENGARUH PEMBIAYAAN MUDHARABAH, PEMBIAYAAN MUSYARAKAH DAN PEMBIAYAAN MURABAHAH TERHADAP RETURN ON ASSETS BANK UMUM SYARIAH DI INDONESIA PERIODE 2012 - 2018
}

\author{
Alifah Susila Hati' ${ }^{1}$ Nana Diana $^{2}$ \\ 1,2Universitas Singaperbangsa Karawang, Jl. HS. Ronggo Waluyo, Puseurjaya, Karawang \\ e-mail: 1610631030024@student.unsika.ac.id
}

\begin{abstract}
Abstrak: Latar belakang dari penelitian ini dimaksudkan untuk mengetahui, menganalisis dan mendeskripsikan pengaruh pembiayaan mudhrabah, pembiayaan musyarakah dan pembiayaan murabahah terhadap Return On Assets (ROA) Bank Umum Syariah di Indonesia Periode 2012 2018. Data pada penelitian ini menggunakan metode penelitian deskriptif verifikatif dengan pendekatan kuantitatif. Dalam penelitian ini, peneliti menggunakan purposive sampling untuk menentukan sampel. Penelitian ini menggunakan data sekunder yang diambil adalah data laporan keuangan tahunan yang di publikasi dari website masing - masing Bank Umum Syariah per tanggal 31 Desember 2012 - 2018. Sedangkan dalam proses analisis data dalam penelitian ini digunakan analisis data dengan software SPSS 26 yang terdiri dari uji asumsi klasik (uji normalitas, uji autokorelasi, uji heteroskedastisitas dan uji multikolinearitas), analisis regresi linear berganda, uji hipotesis (uji t statistik dan uji F statistik) serta uji koefisien determinasi (R2). Hasil penelitian ini diperoleh yaitu variabel pembiayaan mudharabah dan pembiayaan musyarakah tidak memiliki pengaruh terhadap ROA. Sedangkan untuk pembiayaan murabahah memiliki pengaruh positif terhadap ROA. Adapun ketika pembiayaan mudharabah, musyarakah dan murabahah memiliki pengaruh terhadap ROA Bank Umum Syariah.
\end{abstract}

Kata Kunci: Return On Assets, Pembiayaan Mudharabah, Pembiayaan Musyarakah dan Pembiayaan Murabahah. 


\section{PENDAHULUAN}

Munculnya istilah ekonomi syariah di Indoneisa di mulai sejak tahun 1992 yang pada awalnya di dasari karena mayoritas warga negara Indonesia yang beragama Islam. Pencetus perbankan syariah di Indonesia yaitu Bank Muamalat yang didirikan atas kesepakatan Majelis Ulama Indonesia (MUI), Ikatan Cendekiawan Muslim Indonesia (ICMI), serta pebisnis muslim dan tak lupa peran dari pemerintah.

Saat krisis ekonomi di tahun 1998, para pengusaha dibidang perbankan sangat heran, mengapa Bank Muamalat Indonesia bisa tetap tegar menghadapi krisis tersebut yang membuat banyak bank konvensional lesu tak berdaya. Melihat ketegaran Bank Mumalat tersebut, terlahirlah bank dengan sistem syariah yang kedua, yaitu Bank Mandiri Syariah.

Tujuan dari penelitian ini yaitu untuk memberikan masukan kepada Bank Umum Syariah dalam mengelola, bertindak dan mengambil keputusan secara bijak dalam pemberian serta kerja sama dengan nasabah baik dalam pembiayaan mudharabah, pembiayaan musyarakah, dan pembiayaan murabahah yang dapat berpengaruh terhadap Return On Assets Bank Umum Syariah serta mewujudkan kesejahteraan kehidupan masyarakat.

Berdasarkan data yang penulis peroleh, persentase perolehan ROA Bank Umum Syariah tahun 2012 - 2018, bergerak secara fluktuatif akan tetapi cenderung menurun. Jika dilihat secara tahunan, pada tahun 2012 memperoleh persentase sebesar 2,14\%. Dan pada tahun 2013 menurun dengan hanya mendapatkan nilai sebesar 2,00\%. Kemudian terjadi penurunan kembali di tahun 2014 sebesar $0,80 \%$ dan mengalami kenaikan di tahun 2015 sebesar 2,20\%. Dan pada akhirnya mengalami penurunan kembali di tahun 2016 senilai 0,63\% dan angka tersebut menetap sampai di tahun 2017. Namun pada tahun 2018 mengalami kenaikan dengan angka 1,28\%.

Sedangkan berdasarkan data dari Statistik Perbankan Syariah, untuk pembiayaan mudharabah, musyarakah dan murabahah laju perolehan angka nya pun berfluktuatif.

Tabel 1.

Data Pembiayaan Bank Umum Syariah Sejak Tahun 2012-2018

\begin{tabular}{|c|c|c|c|}
\hline Th. & Mudharabah & Musyarakah & Murabahah \\
\hline 2012 & 12.023 & 27.667 & 88.004 \\
\hline 2013 & 13.625 & 39.874 & 110.565 \\
\hline 2014 & 8.424 & 40.278 & 91.867 \\
\hline 2015 & 7.979 & 47.357 & 93.642 \\
\hline 2016 & 7.577 & 54.052 & 110.063 \\
\hline 2017 & 6.584 & 60.465 & 114.458 \\
\hline 2018 & 5.477 & 68.644 & 118.134 \\
\hline
\end{tabular}

Sumber: Statistik Perbankan Syariah, Data Olahan, 2020 
Dapat dilihat dari tabel 1 di atas, untuk pembiayaan mudharabah dari tahun 2012 - 2018 bergerak secara fluktuatif akan tetapi cenderung menurun. Di tahun 2012 memperoleh angka 12.023, tahun 2013 naik dengan nilai 13.625. Namun di tahun 2014 - 2018 perlahan angkanya pun mengalami penurunan. Pada tahun 2014 memperoleh angka 8.424, 2015 hanya senilai 7.979, tahun 2016 turun sebesar 7.577, tahun 2017 di angka 6.585 dan perolehan terkecil ada di tahun 2018 yang hanya menyentuh angka 5.477.

Sedangkan pada pembiayaan musyarakah di lihat dari tabel 1 di atas, memiliki pergerakan yang berfluktuatif juga. Pada tahun 2012 memperoleh angka 27.667, di tahun 2013 mengalami kenaikan dengan nilai 39.874. Keadaan tersebut terus membaik di periode periode selanjutnya, dimana di tahun 2014 sebesar 40.278, di tahun 2015 mengalami peningkatan yang sangat baik dengan perolehan nilai sebesar 47.357. di tahun 2016 memperoleh nilai 54.052, tahun 2017 sbesar 60.465 dan puncaknya berada pada tahun 2018 dengan perolehan tertinggi yaitu sebesar 68.644.

Dari semua jenis produk pembiayaan, pembiayaan dengan akad murabahah merupakan akad yang sangat di minati oleh para nasabah, hal tersebut dapat dlihat pada tabel 1 di atas, laju pada pembiayaan murabahah di mulai dari tahun 2012 - 201 cenderung stabil. Pada tahun 2012 pembiayaan murabahah berada di angka 88.004 dan mengalami peningkatan di tahun 2013 sebesar 110.565. akan tetapi keadaan baik tersebut tidak bertahan lama, dimana pada tahun 2014 terjadi penurunan kembali senilai 91.867, kemudian naik di tahun 2015 dengan angka 93.642, kondisi tersebut sangat baik dan mampu di tingkatkan pada periode beriutnya. Tahun 2016 memperoleh sebesar 110.063, tahun 2017 sebesar 114.458 dan puncaknya terjadi pada tahun 2018, yang berhasil mencatat nilai tertingginya di angka 118.134.

Berdasarkan penjelasan yang telah di paparkan tersebut, peneliti berpendapat bahwa penelitian yang akan dilakukan ini memiliki dampak yang baik bagi perolehan Return on Assets (ROA) serta kepercayaan masyarakat terhadap Bank Umum Syariah.

\section{TINJAUAN PUSTAKA \\ Bank Umum Syariah}

Bank Umum Syariah adalah Bank Syariah yang berdiri sendiri sesuai dengan akta pendiriannya, dan Bank Syariah bukanlah bagian dari Bank Konvesional (Ismail, 2011).

Bank Syariah merupakan sebuah lembaga perbankan yang pada prinsipnya berpegang pada Syariah Islam yang usaha pokoknya memberikan kredit dan jasa - jasa lainnya dengan pembayaran serta peredaran uang yang beroperasi di sesuaikan dengan kaidah Islam. (Yudiana, 2019).

\section{Return On Assets}

Return On Assets (ROA) merupakan rasio untuk mengukur dan menunjukan hasil dari perputaran jumlah kativa yang telah digunakan oleh perusahaan. ROA juga merupakan suat ukuran tentang bagaimana kinerja atau efektivitas manajemen dalam mengelola investasinya. Semakin rendah rasio ini, maka memiliki arti semakin kurang baik efektivitas perusahaan begirupun sebaliknya. (Kasmir, 2017).

Rumus untuk menghitung ROA berdasarkan Surat Edaran Otoritas Jasa Keuangan Nomor 10/SEOJK.03/ 2014 tentang Penilaian Tingkat Kesehatan Bank Umum Syariah dan Unit usaha Syariah tersebut adalah sebagai berikut: 


$$
\mathrm{ROA}=\frac{\text { Laba } \text { Bersih }}{\text { Total } \text { Asset }} \times 100 \%
$$

\section{Pembiayaan Mudharabah}

Pembiayaan mudharabah adalah perjanjian yang dilakukan oleh 2 pihak untuk menjalin kerja sama usaha. Yang mana 1 pihak sebagai pemberi modal dan biasanya ini dilakukan oleh Bank yang disebut dengan shahibul maal dan pihak lainnya atau nasabah disebut dengan mudharib. Perolehan bagi hasil dari usaha tersebut di hitung sesuai dengan nisbah yang telah di sepakati (Ismail, 2011).

Akad mudharabah adalah kerjasama usaha antara 2 pihak dimana pihak pemilik dana menyediakan seluruh modal (100\%), sedangkan pihak pengelola dana menggunakan dan tersebut untuk usaha, dimana nantinya keuntungan usaha dibagi menurut kesepatan yang dituangkan dalam kontrak, sedangkan kerugian ditanggung oleh pihak pemilik dana selama kerugian tersebut bukan disebabkan oleh kelalaian pihak pengelola dana (Khaddafi et.all, 2016).

\section{Pembiayaan Musyarakah}

Pembiayaan musyarakah adalah pembiayaan berbasis bagi hasil, ketika bank dan nasabah menjalin kerja sama untuk melakukan suatu usaha maupun proyek dimana bank menyediakan modal sedangkan nasabah menyediakan keahlian dan modal atau mengerjakan proyek tersebut. (Andriyanto dan Firmansyah, 2019).

\section{Pembiayaan Murabahah}

Pembiayaan murabahah adalah pembiayaan berupa kegiatan jual beli barang sebesar harga perolehan yang ditambah dengan margin keuntungan yang disepakati para pihak yaitu penjual dan pembeli (Andriyanto dan Firmansyah, 2019).

\section{Hipotesis Penelitian}

Agar penelitian lebih terarah, tidak menyimpang, mudah dipahami serta diteliti, maka hipotesis dalam penelitian ini :

H1 : Pembiayaan Mudharabah berpengaruh terhadap ROA.

$\mathrm{H} 2$ : Pembiayaan Musyarakah berpengaruh terhadap ROA.

H3 : Pembiayaan Murabahah berpengaruh terhadap ROA.

H4 : Pembiayaan Mudharabah, Musyarakah dan Murabahah berpengaruh terhadap ROA.

\section{METODE}

Dalam penelitian ini, peneliti menggunakan metode deskriptif verifikatif dengan pendekatan kuantitatif. Dalam penelitian ini, peneliti menggunakan purposive sampling untuk penarikan sampel. Sedangkan dalam proses analisis data dalam penelitian ini digunakan analisis data dengan software SPSS 26 yang terdiri dari uji asumsi klasik (uji normalitas, uji autokorelasi, uji heteroskedastisitas dan uji multikolinearitas), analisis regresi linear berganda, uji hipotesis (uji t statistik dan uji uji F statistik) serta uji koefisien determinasi (R). 
HASIL

\section{Uji Asumsi Klasik}

\section{a. Uji Normalitas}

Tabel 2.

Hasil Uji Normalitas

\begin{tabular}{|l|r|}
\hline \multicolumn{2}{|l|}{ One-Sample Kolmogorov-Smirnov Test } \\
\hline $\mathrm{N}$ & 35 \\
\hline Asymp. Sig. (2-tailed) &, $200^{c, d}$ \\
\hline
\end{tabular}

a. Test distribution is Normal.

Sumber : Data Olahan SPSS Versi 26.

Berdasarkan pada ketentuan pengambilan keputusan, apabila di atas tingkat signifikansi 0,050 dapat dikatakan nilai residual berdistribusi normal. Karena 0,200 > 0,050 maka dapat di simpulkan bahwa data yang digunakan dalam penelitian ini berdistribusi normal.

\section{b. Uji Autokorelasi}

Tabel 3.

Hasil Uji Autokorelasi

\begin{tabular}{|c|c|}
\hline Adjusted R Square & Durbin-Watson \\
\hline, 160 & 1,885 \\
\hline
\end{tabular}

Sumber : Data Olahan SPSS Versi 26.

Tabel 4. Durbin Watson

\begin{tabular}{|c|c|c|}
\hline & \multicolumn{2}{|c|}{$\mathrm{K}=3$} \\
\hline $\mathrm{N}$ & $\mathrm{dL}$ & $\mathrm{dU}$ \\
\hline 35 & 1,283 & 1,653 \\
\hline
\end{tabular}

Sumber : Data Olahan SPSS Versi 26

Dari tabel 3 dan 4 di atas, diperoleh nilai durbin watson sebesar 1,885. Sedangkan berdasarkan nilai DW tabel untuk $d L$ (batas luar) $=1,283$. Besarnya DW tabel untuk $d U$ (batas dalam) $=1,653$. Maka dapat disimpulkan bahwa tidak ada autokorelasi positif atau negatif, karena nilai $d U 1,653<$ nilai DW 1,855. Yang berarti kriteria sesuai dengan dengan data yang diperoleh yaitu $d U<\mathrm{d}$ $<2$.

\section{c. Hasil Uji Heteroskedastisitas Gambar 1. Hasil Uji Heteroskedostistas}

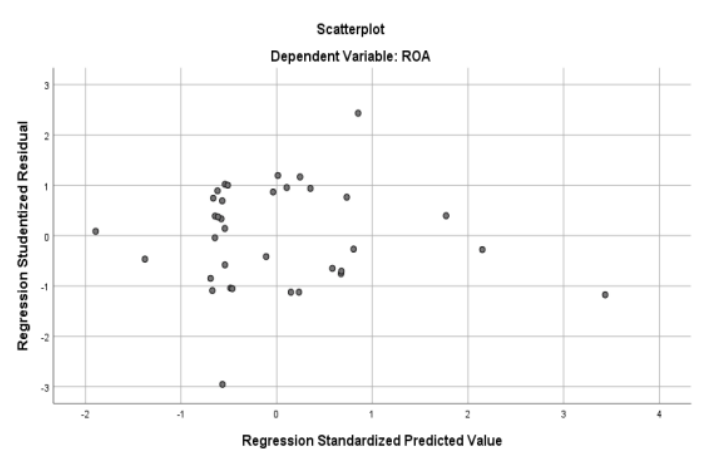

Sumber : Data Olahan SPSS Versi 26.

Melalui hasil pengujian di atas, diperoleh gambar scatterplot yang terdapat titik - titik yang memiliki pola tidak jelas. Serta titik - titik data menyebar di atas dan di bawah atau di sekitar angka 0. Maka dapat dinyatakan analisis regresi berganda di dalam penelitian ini bebas dari gejala heteroskedastisitas.

\section{d. Uji Multikolinearitas} Tabel 5. Hasil Uji Multikolinearitas

\begin{tabular}{|c|l|c|c|}
\hline \multicolumn{3}{|c|}{ Coefficients $^{\mathbf{2}}$} \\
\hline \multirow{2}{*}{ Model } & \multicolumn{2}{c|}{ Collinearity Statistics } \\
\cline { 2 - 4 } & Tolerance & VIF \\
\hline \multirow{4}{*}{1} & mudharabah &, 345 & 2,897 \\
\cline { 2 - 4 } & musyarakah &, 994 & 1,006 \\
\cline { 2 - 4 } & murabahah &, 346 & 2,889 \\
\hline
\end{tabular}

Sumber : Data Olahan SPSS Versi 26.

a. Dependent Variable : roa

Suatu model regresi dapat dikatakan bebas multikolinearitas jika nilai yang dimiliki VIF $\geq 10$ dan apabila TOL $\geq 0,1$. Berdasarkan hasil tabel 4 , diperoleh nilai VIF untuk pengungkapan pembiayaan mudhrabah sebesar 2,897, pembiayaan musyarakah sebesar 1,006 dan untuk pembiayaan murabahah sebesar 2,889. Artinya nilai VIF ketiga 
variabel bebas tersebut berada diantara nilai sampai dengan 10. Dan untuk nilai TOL ketiga variabel bebas tersebut memiliki nilai TOL lebih dari 0,1. Diantaranya pada pembiayaan mudharabah nilai TOL 0,345 , pembiayaan musyarakah nilai TOL 0,994 dan pembiayaan murabahah nilai TOL 0,346. Dengan demikian dapat disimpulkan bahwa data terbebas dari gejala multikolinearitas.

\section{e. Analisis Regresi Linear Berganda}

Model persamaan regresi yang digunakan dalam penelitian ini adalah sebagai berikut:

$$
Y=a+b_{1} X_{1}+b_{2} X_{2}+b_{3} X_{3}+e
$$

Sumber: Sugiyono, 2017.

Berdasarkan hasil output data yang diolah dengan menggunakan SPSS, diperoleh persamaan regresi sebagai berikut :

Return On Assets (Y) = 0,577 - 1,332(x1)

$+1,425(\mathrm{x} 2)+2,228(\mathrm{x} 3)+\mathrm{e}$.

\section{Uji Hipotesis}

\section{a. Uji-t (Parsial)}

Uji Parsial atau Uji-t dapat digunakan untuk melihat bagaimana pengaruh masing-masing variabel yaitu variabel bebas dan variabel terikat.

Tabel 6.

Hasil Uji-t (Parsial)

Sumber: Data Olahan SPSS Versi 26.

\begin{tabular}{|c|c|c|c|}
\hline \multirow{2}{*}{ Variabel } & Unstandarized Coeficients & \multirow{2}{*}{$T$} & \multirow{2}{*}{ Sig } \\
\cline { 2 - 2 } & $\mathrm{B}$ & & \\
\hline (Constant) & 0,577 & 3,986 & 0,000 \\
\hline Mudharabah & $-1,332$ & $-2,005$ & 0,054 \\
\hline Musyarakah & 1,425 & 2,015 & 0,053 \\
\hline Murabahah & 2,228 & 2,431 & 0,021 \\
\hline
\end{tabular}


Untuk mencari nilai tabel dengan menggunakan rumus berikut ini :

$$
\mathrm{T}_{\text {tabel }}=\mathrm{t}(a / 2 ; \mathrm{n}-\mathrm{k}-1)
$$

Dari rumus di atas, dapat disimpulkan bahwa tabel $=\mathrm{t}(0,025 ; 31)=$ 2,040. Setelah mendapatkan nilai tabel kemudian dapat dibuatkan kesimpulan menerima atau menolak hipotesis sebagai berikut :

\section{Pengaruh}

pembiayaan

\section{mudharabah terhadap return on} assets.

Berdasarkan hasil pengujian nilai thitung sebesar -2,005. Jika dibandingkan dengan nilai tabel yaitu 2,040. Sehingga nilai thitung $-2,005<$ nilai tabel 2,040. Serta nilai signifikansi sebesar 0,054 lebih besar 0,05. Dengan demikian, $\mathrm{H}_{1}$ ditolak. Yang berarti bahwa tidak terdpat pengaruh antara pembiayaan mudharabah terhadap ROA.

\section{Pengaruh pembiayaan musyarakah terhadap return on assets.}

Berdasarkan hasil pengujian diperoleh nilai thitung sebesar 2,015. Jika dibandingkan dengan nilai tabel yaitu 2,040. Sehingga nilai thitung 2,015 < nilai ttabel 2,040. Serta nilai signifikansi sebesar 0,053 lebih besar dari 0,05. Dengan demikian dapat disimpulkan $\mathrm{H}_{2}$ ditolak, yang berarti bahwa tidak terdapat pengaruh antara pembiayaan musyarakah terhadao ROA.

\section{Pengaruh pembiayaan murabahah terhadap return on assets.}

Berdasarkan hasil pengujian di peroleh nilai thitung sebesar 2,431. Jika dibandingkan dengan nilai tabel yaitu 2,040. Sehingga nilai thitung 2,431 > nilai ttabel 2,040. Serta niali signifikansi sebesar 0,021 lebih besar dari 0,05. Dengan demikian dapat disimpulkan $\mathrm{H}_{3}$ diterima. Yang berarti terdapat pengaruh positif antara pembiayaan murabahah terhadap ROA.

\section{b. Uji F (simultan)}

Tabel 7.

Hasil Uji F

\begin{tabular}{|c|c|c|}
\hline \multicolumn{3}{|c|}{$A N O V A$} \\
\hline \multirow{2}{*}{ Regresion } & $\mathrm{F}$ & Sig \\
\hline & 3,161 & $0,038^{b}$ \\
\hline
\end{tabular}

Sumber : Data Olahan, 2020

Dari tabel 7 di atas, terlebih dahulu harus ditentukan nilai - nilai $F_{\text {tabel. Nilai }} F_{\text {tabel }}$ dapat ditentukan dengan menggunakan rumus sebagai berikut :

$$
\mathrm{F}_{\text {tabel }}=\mathrm{F}(\mathrm{k} ; \mathrm{n}-\mathrm{k})
$$

Setelah menggunakan rumus diatas untuk mencari dapat dihitung bahwa nilai $F_{\text {tabel }}$ dalam penelitian ini adalah $F_{\text {tabel }}=\mathrm{F}(3 ; 31)=2,91$. Selanjutnya, nilai $F_{\text {hitung }}$ dengan nilai $F_{\text {tabel. }}$ Sehingga diperoleh nilai 3,161 > 2,91. Artinya, nilai $F_{\text {hitung }}$ lebih besar dari nilai $F_{\text {tabel. Nilai signifikansi senilai } 0,038}$ lebih besar dari 0,05. Dengan demikian, dapat disimpulkan bahwa terdapat pengaruh pembiayaan mudharabah, musyarakah dan murabahah terhadap ROA secara bersama - sama (simultan).

\section{Koefisien Determinasi}

Tabel 8.

\section{Hasil Uji Koefisien Determinasi}

\begin{tabular}{|r|r|}
\hline Adjusted R Square & Durbin-Watson \\
\hline 0,160 & 1,885 \\
\hline
\end{tabular}

Pada tabel 8 di atas, diperoleh nilai adjusted $R$ Square sebesar 0,160 atau $16 \%$. Hal ini menunjukan bahwa nilai variabel yang diteliti yaitu pembiayaan mudharabah, musyarakah dan murabahah berpengaruh sebesar $16 \%$ terhadap ROA. Sedangkan sisanya 
yaitu 84\% dipengaruhi oleh variabel lain yang tidak di teliti dalam penelitian ini.

\section{PEMBAHASAN}

Penelitian ini terdiri dari 4 variabel, yaitu Pengaruh Pembiayaan Mudhrabahah, Pembiayaan Musyarakah dan Pembiayaan Murabahah Terhadap Return On Assets Bank Umum Syariah di Indonesia Periode 2012 - 2018. Berikut penjelasan verifikatif untuk masingmasing variabel penelitian :

\section{a. Pengaruh Mudharabah Terhadap Return On Assets.}

Berdasarkan hasil pengujian yang telah dilakukan, diperoleh nilai thitung sebesar sebesar -2,005. Jika di bandingkan dengan nilai tabel yaitu 2,040. Sehingga nilai thitung $-2,005<$ nilai ttabel 2,030. Serta nilai signifikansi sebesar 0,054 lebih besar dari 0,05. Dengan demikian, $\mathrm{H}_{1}$ ditolak. Yang berarti bahwa tidak terdapat pengaruh antara pembiayaan mudharabah terhadap Return Assets (ROA). Selain itu dengan hasil tersebut, dapat dijelaskan apabila terjadi kenaikan ataupun penurunan pada pembiayaan mudharabah maka hal tersebut tidak di ikuti oleh perolehan Return On Assets.

Tidak berpengaruhnya pembiayaan mudharabah terhadap ROA menurut Direktur Keuangan dan Operasional Bank Muamalat, Herdianto, dilansir dari www.republika.co.id pada 16 April 2014, mengatakan penyebab dari resiko pembiayaan mudharabah karena hasil dari pembiayaan mudharabah tidak pasti. Jika usaha sedang mengalami penurunan maka jumlah bagi hasil pun ikut menurun. Begitupun ketika usaha naik maka bagi hasil pun akan mengalami peningkatan pula.
Hal yang menjadi faktor penyebab tidak berpengaruh nya pembiayaan mudharabah terhadap ROA pula menurut Presiden Direktur Maybank Syariah Indonesia, Norfadelizan Adul Rohman, dilansir dari www.republika.co.id mengatakan penyebab nya berupa sebagian bank umum syariah melakukan pembiayaan kepada perorangan, artinya ada kemungkinan bank salah menyalurkan dan mudah mengalami atau rentan terhadap penyimpangan yang dilakukan oleh nasabah, berupa nasabah tidak jujur dalam melaporkan laporan keuangan bisnisnya. Serta bank mengalami keterbatasan dalam mengetahui kegiatan - kegiatan yang dilakukan mudharib.

\section{b. Pengaruh Pembiayaan Musyarakah Terhadap Return On Assets}

Berdasarkan hasil pengujian di peroleh nilai thitung sebesar 2,015. Jika di bandingkan dengan nilai tabel yaitu 2,040. Sehingga nilai thitung 2,015 < nilai ttabel 2,040. Serta nilai signifikansi sebesar 0,053 lebih besar dari 0,05. Sehingga dapat di simpulkan $\mathrm{H}_{2}$ ditolak. Yang berarti bahwa tidak terdapat pengaruh antara pembiayaan musyarakah terhadap Return Assets (ROA). Maka karena hasil tersebut, dapat dijelaskan apabila terjadi kenaikan ataupun penurunan pada pembiayaan musyarakah maka hal tersebut tidak berdampak terhadap perolehan return on assets.

Tidak berpengaruhnya pembiayaan musyarakah terhadap ROA menurut Junaedi D. Kamil, SH,ME,CRA di lansir dari www.analisadaily.com berpendapat, hal tersebut dapat terjadi kemungkinan terdapat kerugian dari hasil usaha/ proyek yang dibiayai dan ketidak jujuran dari mitra usaha. Serta 
terbatasnya kualitas dan kuantitas sumber daya insani yang dimiliki bank umum syariah, misalnya terlalu mudah memberikan modal terhadap nasabah, lemahnya kemampuan bank dalam mendeteksi kemampuan nasabah untuk membayarakan angsuran serta kurangnya jumlah staff yang memahami skema pembiayaan musyarakah.

\section{c. Pengaruh Pembiayaan Murabahah Terhadap Return On Assets}

Berdasarkan hasil pengujian di peroleh nilai thitung sebesar 2,431. Jika di bandingkan dengan nilai tabel yaitu 2,040. Sehingga nilai thitung $2,431>$ nilai ttabel 2,040. Serta nilai signifikansi sebesar 0,021 lebih besar dari 0,05. Sehingga dapat di simpulkan $\mathrm{H}_{3}$ diterima. Yang berarti bahwa terdapat pengaruh positif antara pembiayaan murabahah terhadap Return Assets (ROA). Selain itu hasil tersebut yang menunjukan thitung memiliki nilai positif, maka dapat dijelaskan ketika pembiayaan murabahah mengalami kenaikan maka kenaikan pula akan terjadi pada perolehan return on assets nya, dan ketika pembiayaan murabahah mengalami penurunan maka hal tersebut juga akan terjadi pada perolehan return on assets.

Adanya pengaruh pembiayaan murabahah terhadap ROA menurut para ahli Ekonomi Islam, di lansir dari www.kompasiana.com dapat disebabkan karena pembiayaan murabahah sepadan dengan pola perbankan konvensional. Yang menyebabkan pembiayaan ini mudah di pahami oleh bank maupun masyarakat. Selanjutnya, pada pembiayaan murabahah memiliki kemudahan dalam memberikan jasa sekaligus mengandung resiko yang relatif lebih kecil.

\section{SIMPULAN}

Berdasarkan penelitian dan
pembahasan yang dilakukan oleh
penulis, maka dapat diambil beberapa
kesimpulan, yaitu: kesimpulan, yaitu :

1. Berdasarkan hasil uji $\mathrm{t}$ (parsial) di peroleh nilai thitung sebesar -2,005. Jika di bandingkan dengan nilai tabel yaitu 2,040. Sehingga nilai thitung $2,005<$ nilai ttabel 2,040. Serta nilai signifikansi sebesar 0,054 lebih besar dari 0,05. Yang berarti bahwa tidak terdapat pengaruh antara pembiayaan mudharabah terhadap Return Assets (ROA).

2. Berdasarkan hasil uji $\mathrm{t}$ (parsial) di peroleh nilai thitung sebesar 2,015. Jika di bandingkan dengan nilai tabel yaitu 2,040. Sehingga nilai thitung $2,015<$ nilai ttabel 2,040. Serta nilai signifikansi sebesar 0,053 lebih besar dari 0,05. Yang berarti bahwa tidak terdapat pengaruh antara pembiayaan musyarakah terhadap Return Assets (ROA).

3. Berdasarkan hasil uji $\mathrm{t}$ (parsial) di peroleh nilai thitung sebesar 2,431. Jika di bandingkan dengan nilai tabel yaitu 2,040. Sehingga nilai thitung $2,431>$ nilai tabel 2,040. Serta nilai signifikansi sebesar 0,021 lebih besar dari 0,05. Yang berarti bahwa terdapat pengaruh antara pembiayaan murabahah terhadap Return Assets (ROA).

4. Terdapat pengaruh pembiayaan mudharabah, pembiayaan musyarakah dan pembiayaan murabahah terhadap Return On Assets (ROA) secara bersama. Hal ini dapat dilihat pada hasil uji $\mathrm{F}$ yang membuktikan bahwa didapat nilai signifikansi sebesar $0,038>0,05$ dan $F_{\text {hitung }}(3,161)>F_{\text {tabel }}(2,901)$. Maka $\mathrm{Ha} 4$ diterima, yang berarti terdapat pengaruh pembiayaan 
mudharabah, pembiayaan musyarakah, dan pembiayaan murabahah terhadap Return On Assets (ROA) secara bersama sama.

\section{DAFTAR RUJUKAN}

Andrianto, \& Firmansyah, A. M. (2019). Manajemen Bank Syariah. Surabaya: CV. Penerbit Qiara Media.

Faradilla, C., Arfan, M., \& Shabri, M. (2017). Pengaruh Pembiayaan Murabahah, Istishna, Ijarah, Mudharabah dan Musyarakah Terhadap Profitabilitas Bank Umum Syariah Di Indonesia. Jurnal Magister Akuntansi Pascasarjana Universitas Syiah Kuala, 10 - 18. Vol. 6 No. 3, Agt 2017. ISSN : 2302-0164.

Ismail. (2011). Perbankan Syariah. Jakarta: Prenadamedia Group.

Kasmir. (2014). Bank dan Lembaga Keuangan Lainnya. Jakarta: PT. Raja Grafindo Persada.

Khadaffi, M., Siregar, S., Noch, M. Y., Nurlaila, Harmain, H., \& Sumartono. (2016). Akuntansi Syariah Meletakkan Nilai - nilai Syariah Islam dalam Ilmu Akuntansi. Medan: Madenatera.

Nuryani, K., \& Tandika, D. (2019). Pengaruh Pembiayaan Murabahah, Mudharabah dan Musyarakah Terhadap Tingkat Return On Assets (ROA) pada Bank Syariah Mandiri Periode 2013-2017. Prosiding Manajemen, 496 - 502. Vol. 5 No. 1. ISSN : 2460-6545. Universitas Islam Bandung.

Riyadi, S., \& Yulianto, A. (2014). Pengaruh Pembiayaan Bagi Hasil, Pembiayaan Jual Beli, Financing to Deposit Ratio (FDR) dan Non Performing Financing (NPF)
Terhadap Profitabilitas Bank Umum Syariah di Indonesia. Accounting Analysis Journal, 466 474. ISSN : 2252-6765. Universitas Negeri Semarang.

Sari, M. (2015). Pengaruh Pembiayaan Mudharabah, Pembiayaan Musyarakah dan Pembiayaan Murabahah Terhadap Profitabilitas Pada Bank Syariah Mandiri dan Bank Muamalat Indonesia (Studi pada Bank Umum Syariah yang Terdaftar di Bank Indonesia . AKUNIDA, Vol. 2 No. 1, June 2015. ISSN : 24423037. Universitas Djuanda Bogor. Yudiana, F. E. (2014). Manajemen Pembiayaan Bank Syariah. Salatiga, Jawa Tengah: STAIN Salatiga Pers. 